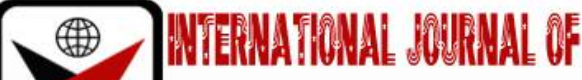

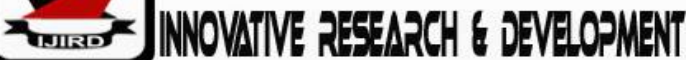

ISSN 2278 - 0211 (Online)

\section{The Structure of the Nigerian Economy and Electoral Violence: Implications for Political Participation in Nigeria}

\begin{tabular}{c} 
Anthony Chinonso Ajah \\
Ph.D. Student, Department of Political Science, \\
University of Nigeria, Nigeria \\
Ukachi Clementia Uche \\
Senior lecturer, Department of Horticulture andLandscape Technology, \\
Federal College of Agriculture, Nigeria \\
MerinoeChukwudiOkiriaja \\
Civil Servant, Department of Political Science, \\
University of Nigeria, Nigeria \\
\hline
\end{tabular}

\begin{abstract}
:
The Nigerian economy is a middle-income that has agriculture and the government as the major source of employment. Though in principle, the country is a mixed economy where the means of production are own and control between the government and the private sectors, but in practice, there is an overconcentrationof economic powers on the government. This monopoly is yet compounded by the 'winner takes all' formula implicit in the constitution. Also, the absence of runner-up value and the enormous executive power explicit in the Nigeria federalismfurther made winning an election a lot more profitable than just governance. Therefore, instead of aiding a peaceful transition of power, election often turnsinto a battlefield due to theselfish interests of the dominant class.In this way, political actors, therefore, employ every means during elections to capture political power. UsingMarxian theory of the post-colonial state,the paper concludes that the nature of the Nigerian fiscal federalism which over-centralized economic powers on the government made political officean avenue for personal aggrandizement, and thus, breeds corruption and election violence. Therefore, the battle for the control and distribution of national wealth raises the stake and likelihood of violence during elections. The implication for political participation was outlined and the study recommends for a constitutional review that will empower states to use their resources to develop their region.
\end{abstract}

Keywords: Nigeria, economic structure, electoral violence, political participation

\section{Introduction}

This paper established a nexus between the structure ofthe Nigerian economy and electoral violence. It argues that the battle for the control and distribution of national wealth raises the stake and likelihood of violence during elections.

One of the major characteristics of modern democracy is frequent elections. Election represents the most acceptable process of legitimizing a government; ensuring competitive politics, equal representative, level playing field, and most importantly, majority rule (Beetseh and Akpoo, 2015). However, since independency, the Nigerian democracy has witnessed a plethora of electoral violence and malpractices, which includes but not limited to armed thuggery, falsification of election results, the kidnapping of opponents and election officials, hijacking of sensitive election materials, and disruption of the election process (Ojukwu, Mbah, and Maduekwe, 2019). To this end, literature has struggled to pinpoint the actual cause of electoral violence in Nigeria. As we shall discuss later in the literature review, scholars have subjected this to different analytical and theoretical perspectives, but in this paper, we shall pin it down on the structure of the economy using the Marxian theory of Post-colonial State, which according to this study inflates the struggle for primitive accumulation of values.

Historically, looking at the background to the Nigeria fiscal federalism, which undoubtedly, influenced the structure of the Nigeria economy,Edo and Ikelegbe (2014) argue that following the end to the Nigerian civil war and the institutionalization of the military regime, governmentpolicies began to shrink the participation of foreign and private firms, resulting togovernment monopolizing the critical sectors of the economy. This policy thus concentrates so much economic and administrative power on the central government, thereby given them grip control over the production, allocation, and distribution of resources. In their analysis, Kwarkye (2019) and Kingston and Gogo (2016) explain that aside from the indigenization policy which gave the central government firm control over the economy, the land use Act of 1978 and the 1969 petroleum Act handed over all land and the oil deposits in it to the central government. This 
includes the exclusive right to oil exploration licenses, oil prospection licenses and oil mining licenses; rights of preemption; repeals; and transitional and savings provisions (Petroleum Act, 1969, 1990). Though the oil sector remains a joint venture between foreign drilling companies and the Nigerian National Petroleum Corporation (NNPC), the federal government remains in control of the production, and the distribution of oil revenue through a complex sharing formula with the 36 states of the federation (Kwarkye, 2019).

Forrest (2014) in his study of the 'political economy of civil rule' found that the Nigerian fiscal federalism overcentralized both the financial and administrative power on thecentral government. In this configuration, other components of the government technically depend on the centre for their functionality. This economic monopoly, unviability of the State governments, and non-competitiveness of the private sector, therefore, created too much dependency and reliance on federal allocations for states, jobs, and empowerment for individuals. Furthermore, the arrival of oil revenue, political competition by ethno-religious groups, communities, and individuals over access to the national resources through representatives at the centrebegan to pile allocation and distribution pressure on the centre, thereby, giving room for corruption, nepotism, and constraintstoeconomic growth and development (Kwarkye, 2019).In their 'modelling of fiscal policy,' CBN (2013) observes that the structure of Nigerian fiscal federalism has left states and local governments with very little revenue of their own, even the private sector, which ideally, should be the driver of the economy has been relegated to the bottom (Mordi,Englama, and Adebusuyi, 2008).

Studies contend that the Nigerian economy was structured to serve the interest of the dominant class (Odigbo, 2017; Onah and Nwali, 2018; Acemoglu, 2013). The economic policy direction, thus, validates this claim based on the availability of enabling business environment, infrastructure, and policy implementation. There exists a kind of patronclient relationship between the centre and private sector where the functionality of the later depends on the patronage of the formal (Acemoglu, 2013). Therefore, this made whoever controls the government so powerful, his party powerful, and those that have access to him powerful. Since politics is a game of 'who gets what, when and how', the struggle to control the power of the state becomes a struggle to control the national wealth and the authoritative allocation of values (Onapajo, 2014). Besides, it is a common saying that 'who play the pipe dictates the tune'- it is the people or party that control the government that dictate who; either group orregion that will benefit more from state's projects, empowerment and resources allocated (Agbu, 2016). Therefore, this scenario made political parties, ethnic groups, and powerful individuals to tie their destiny on the outcome of an election. To various ethno-political groups, and political parties, losing an election means sitting out of the corridor of power, and by implication going hungry or staying marginalized for years (Onuoha and Ikelegbe, 2018). Having one's party in government is fundamentally essential and a mission that must be achieved by all possible means no matter the cost. In recent times, it has become a sad reality that for an individual or group of individuals to secure a well-paid job, such a person must have a political connection. A political connection has also become a gateway to getting contracts, patronage, and access to foreign exchange by the private sector. Then too, to work in big sectors like the Oil and Gas sector, Federal Inland Service, Central Bank of Nigeria, Nigeria Deposit Insurance Corporation, Nigeria Ports Authority, among others, one may need a political connection. To compound an already complex issue, both the security chiefs and chairman of the electoral umpire are appointed, funded, and directed by the central government (Kingston and Gogo, 2016; Iwuoha, 2018; Ituma, 2017; Adetwa, 2015). For this reason, politicians and their financers become desperate to win by all means during election seasons. As a result, all forms of violence and malpractices which include but not limited to killing, intimidation, thuggery, vote-buying, hijacking of sensitive electoral materials, use of the military and other security agencies against political opponents, inducing the electoral umpire, among others, become viable option to win an election (Onah and Nwali, 2018; Onuoha and Ikelegbe, 2018).

As a corollary of the above, this paper took a departure and offers a more analytical depth using the Marxian theory of the post-colonial state in explaining how and why the structure of the Nigerian economy promotes election violence. It also examines the implications of election violence on political participation in Nigeria. The study was divided into four sections: the introduction, literature review, theoretical framework,discussion conclusion, and recommendations.

\subsection{Conceptual Clarifications}

In this section, important concepts will be defined

\subsubsection{Structure}

Ahmady, Mehrpour, Nikooravesh (2016) see Structure as the relations between the components of an organized whole. Thus, the structure concept can be used for everything. For example, a building is a structure of the relationship between foundation, skeleton, ceiling, and wall. The body of a human being is a structure that consists of the relations between bones, organs, blood, and tissues. But in the context of this paper, the structure is used to refer to the form and pattern of the Nigerian economy, in other words, the nature and characteristics of the Nigerian economy.

\subsubsection{Nigerian Economy}

This concept is used to refer to the political economy of Nigeria and the control of the means production. Theoretically, Nigeria practices a mixed economy where the state and public sector drive an independent means of the production and distribution of goods and services, but in practice, the Nigerian government control through policies (formulation and implementation) every major means of production in Nigeria. These policies can be in the form of tax waving, access to foreign exchange among others. 


\subsubsection{Electoral Violence}

Violence in this context means aggression to injure or destroy. As such, electoral violence according to Peter and AbdulRahman (2018) refers to the act of using violence to influence an electoral process through threat, verbal intimidation, hate speech, misinformation, physical assault, kidnapping, blackmail, destruction of property, or the assassination of opponents, electoral officials or perceived threat. This definition captured the usage in this study.

\subsubsection{Political Participation}

Political participation includes a broad variety of political events in which people share their political opinions and contribute to how they are governed. Such participation includes, among others, contributing to individual or collective social concerns, lobbying, political party membership, voting and contesting elections. Falade (2014) perceives it as an element of political behaviour, which reflects on how individuals engage in politics. This is a voluntary activity, and one can directly or indirectly take part. The various ways in which people can become involved in the political system include the appointment or election of political leaders, policy formulation, community activities, and other civic engagements.

\section{Literature Review}

For decades, important studies have been published on the causes of electoral violence in Nigeria. For instance, Kalu and Gberevbie(2017), Ojo (2014), Obakhedo (2011), Ladan-Baki (2016), Ikyase and Egberi (2015) in their studies which centred on electoral violence and democracy in Nigeria, argued that among other things, the lack of internal party democracy is the main catalyst triggering violence during elections. They defined internal party democracy as the strict adherence to democratic principles within the parties' internal arrangement. This can be observedin terms of mobilization, orientation, the nomination of candidates, campaigning, and among others. Electoral violence has remained a prominent threat negating democratic consolidation in Nigeria.

Aside from the lack of internal democracy, literature also identified unemployment and impunity among political leaders as major contributing factors to electoral violence (Onimisi, 2015; Agbalajobi and Agunbiade, 2016; Onimisi and Tinuola, 2019). They contend that youth's unemployment and the need to satisfy basic human needs have caused young people to engage in political thuggery as a means of survival. Also, political elites and their financers organize election violence through their support base (Daxecker, 2019). Onimisi and Tinuola (2019) further expanded this premise and explain that the culture of impunity, corruption, and the failure of the law enforcement agencies to bring to book electoral offenders have made electoral violence low risk- high benefit venture (Orji \&Uzodi, 2012). Using party-centred theory, Daxecker (2019) argues that electoral violence does not just happen, rather, it a strategy employed by political parties to influencethe election outcomes. The political actors and their partiesnow rely on the use of violence to achieve political gain; this is largely because the inclination of the state and the law enforcement agencies to prosecute electoral offenders is low or none existing. The cause of electoral violence in Nigeria is inexhaustible; Verjee, Kwaja, and Onubogu (2018), in their opinion believe that rather than the lack of internal party democracy, unemployment, and impunity; electoral violence is caused by ethnic politicsand corruption. To them, candidates, rather than having national acceptability are seen as representing certain ethnicity and religious group. In some cases, political parties are configured along ethnic lines. More often than not, political parties or candidates themselves, when faced with strong competition for political power, employ sectional or religious sentiment, to divided or draw certain sympathy. No wonder electoral violence in Nigeria easily turns into ethnic and religious crises (Onimisi and Tinuola (2019; Orji \&Uzodi, 2012).

Notwithstanding these prominent views identified, literature isstill replete with irreconcilable perspectives. Different schools of thought have continued to advance their positions and views on what they believe is the cause of electoral violence in Nigeria (Shanky-Ula, 2010). Sisk (2010), Ugaibe (2010), and Yusuf (2019) insist that the lack of strong institutions prosecute electoral offenders no matter how highly placed in the society and the gross abuse of office by elected officials constitute the two major factors that increase electoral violence in Nigeria. Although these views enriched our understanding of the causes of electoral violence in Nigeria, they failed to aggregate the role of the economy and the struggle among elites for wealth accumulation as the major factor that causes violence during elections in Nigeria. Therefore, this paper will fill this important gap

\subsection{Theoretical Framework}

This paper adopted the Marxian Theory of Post-Colonial States (MTPCS) in explaining the root cause of electoral violence in Nigeria. The MTPCS is an offshoot of the Marxian political economy paradigm, which emphasis material conditions of existence in the analysis of political phenomenon (Ake, 1981; Abada, Ifeoma, and Stanislaus, 2018). The theory has been modified and advanced in the study of post-colonialism by scholars such as Alavi (1973), Ekekwe (1985), Ake (1985), and Ibeanu (1998). The theory views the post-colonial states like Nigeriaas structured to promote and sustain the interest of the political class. Built on the western capitalist apology, the Nigerian economy is entangled in the neo-colonial agenda of western capitalism based on profit and primitive accumulation of wealth.

The neo-colonial agenda passed down and built on a weak economic structure that aid corruption, selfaggrandizement, and struggle for resources among the elites failed to reflect the cultural heritage of the African societies. Even at that, the dominant class is not ready to foster development nor surrender their position and restructure the economic and political system to reflect and accelerate development (Adibe and Mbaegbu, 2017). Since the dominant class uses the State as an instrument of private accumulation of wealth, economic stability becomes a mirage. To further this, Ibeanu contends that: 
Colonial state due to its distinct colonial experience at the stage of extensive growth of capital emerged principally for conquering and holding down the peoples of the colonies, not as an equal commodity bearer in integrated national markets, but as occasional commodity producers. As a result of this, there was no effort made to resolve and institutionalize principles for non-arbitrary use of the colonial State by the colonial political class. In the post-colonial era, the state passed into the hands of a pseudo capitalist class who seeking fervently to become economically dominant, becomes for the controllers, a powerful instrument for acquiring private wealth, a monstrous instrument in the hands of individuals and pristine ensembles for pursuing private welfare to the exclusion of others (Ibeanu, 1998: 9-10).

\subsection{Structure of the Nigerian Economy}

Nigerian Postcolonial State has remained a state where the primitive accumulation of wealth flourishes (Abada et al, 2018). It was structured to reinforce the reproduction of the interest of the political class. This structure was institutionalized through the power-sharing configuration of the Nigerian fiscal federalism. Nigerian federalism is structured in a manner that the centre controls critical aspects of the economy through policy formulation and grip control of the means of production (Ovwasa, 1995). Kapucu (2018) observes that Fiscal federalism was a creation of the colonial government and handed down to the political elites after independence. However, Ekpo and Englama (2008) lament that the structure of Nigerian fiscal federation in terms of resource allocation and management has remained a serious issue undermining national development. Although the concept of fiscal federalism is often seen by the World Bank as a vehicle of promoting governance and development in third world countries such as Nigeria, Ekop and Englama argue that:

...The situation in Nigeria is, however, different. The paradox of Nigeria's fiscal system is that it focuses more attention on 'sharing' than 'generating'. In other words, increased revenue generation has attracted less attention than revenue sharing. This is because oil remains the highest contributor to the distributable pool of the federation. The over-dependence on oil has become a propelling wind of regional agitations instead of energizing efforts towards diversification of the economic base for a virile and durable economy. For instance, the crisis in the Niger Delta has been traced to inequitable fiscal systems among others (Ekpo and Englama, 2008, p. 221-222).

The structure of the Nigerian economy and the resource allocation formula remain lopsided serving the interest of the elites while impoverishing the masses. This supports the fact that the Nigerian economy was built on a faulty political foundation; a structure that inhibits economic stability while enriching few at the expense of the vast majority of the masses.

Since 1946, following the established of three regions by the Richard constitution, the daunting challenges of resource politic of 'who gets what' has persisted. Instead of sharing revenue among the regions based on IGR (internally generated revenue), the colonial power decided to allocate more to less productive, but backward region to enable them to compete with the rest of the country.This justified the assumption of this paper that the Nigerian fiscal regime is more or less a political movement drafted by the western imperialism for continued economic colonialization of Nigeria (Ekpo and Englama, 2008).

The uncertainty that accompanied the lopsidedness of the Nigerian economy and the unending struggle for resource control among the dominant class has continued to take a central stage in the agitating for restructuring in Nigeria. In sort, the clamouring for restructuring and true federalism has featured prominently in Nigerian politics in recent times. In the 2015 and 2019 elections, restructuring was the focal point and agenda of the southern leaders, while the north favoured the status quo (Bakare, 2016; Oladeji, 2008; Aderonmu, 2010). In the analysis of the challenge of Nigerian federalism and the call for restructuring, Mba, (2018) in his opinion asserts that:

The crux of the matter lies in the fact that the federal government has too much power, plays the dominant role and overbearing influence which has been grossly abused-thus leading to intensified calls for restructuring coupled with suppressed frustrations and resentment during the long years of military rule resulting in inter-communal violence-While the national question has taken the center stage with sections of the country crying marginalization in terms of development and occupation of strategic positions, there is the issue of resource control and the fact that the federating units never had discussions or negotiations to become one. These have heightened activities of various ethnic militant groups such as Odua Peoples' Congress, Arewa Peoples' Congress, Niger Delta Militants, Independent People of Biafra, the Boko Haram insurgency among others and generated conflicting views and interests on the continuing existence of Nigeria as a federation, hence the call for true federalism and restructuring (Mba, 2018, p. 3)

Furthermore, Onuigbo and Eme (2015) observe that one of the contentious issues in the 2014 national conference is the clamour for the restructuring of the Nigerian economy through a reengineered fiscal federalism. Table 1 highlights some of the tax and revenue jurisdictions of the Nigerian federalism 


\begin{tabular}{|c|c|c|c|c|}
\hline S/N & Tax & Jurisdiction & Collection & Retention \\
\hline & Import duties & Federal & Federal & Federation Account \\
\hline & Petroleum Revenue & Federal & Federal & Federation Account \\
\hline & Mining rents \& royalty & Federal & Federal & Federation Account \\
\hline & Export duties & Federal & Federal & Federation Account \\
\hline & Excise duties & Federal & Federal & Federation Account \\
\hline & $\begin{array}{c}\text { Personal income tax: armed \& police forces, } \\
\text { external affairs officers, non-residents, residents } \\
\text { of the Federal Capital Territory }\end{array}$ & Federal & Federal & Federation Account \\
\hline & Value-added tax & Federal & Federal & Federation Account \\
\hline & Company tax & Federal & Federal & Federation Account \\
\hline & Capital gains tax & Federal & State & State \\
\hline & Licenses and fees & Local & Local & Local \\
\hline & Motor park dues & State & Local & Local \\
\hline & Motor vehicle & State & Socal & Local \\
\hline & Pools betting and other betting taxes & State \\
\hline & Land registration and survey fees & State & State & State \\
\hline & Market and trading license and fees & State & Local & Local \\
\hline & Capital transfer tax (CTT) & Federal & State & State \\
\hline
\end{tabular}

Table 1: Nigeria's Federal, State, and Local Revenue and Tax Jurisdictions

Source: Salami (2011)

\subsection{Elites Competition and Election Violence}

There are several reasons identified in the literature as to why election violence persists in Nigeria. Notwithstanding, this section argues that greed for political power and its associated material wealth is the prominent cause of election violence in Nigeria. Ashindorbe (2018) in his opinion sees electoral violence as 'all types of organized action or threats of a physical psychological and systemic nature' aimed at threatening, harming, and blackmailing a political opponent before, during, and after an election, intending to influence the outcome of the electoral process. There are indications that candidates or political parties with strong and institutionalized local thugs have more capacity to win elections through violence. Such a view of candidates or parties with strong and diverse local support having more chance of influencing outcome with violence during the election was developed and expanded by Daxecker (see Daxecker, 2019).

We argue that the battle for the accumulation of national wealth by the political elitesis often plotted to divide the nation along ethno-religious lines. If that's true, it is also true that fractionalization along ethnic lines is a tactic for the selfish pursuit of public office in a mask of embodiment, and pretence such represents the group's ambition. Through hate speech and patronage of ethnic sentiment, self-aggrandizement and exploitative nature of the political elites make election violence more likely. For example, the 2011 electoral violence that threatened the stability of Nigerian democracy can be traced to the political leaders' utterances, rhetoric, and body language in the building up to the election. The 2011 election violence is considered the worst in recent memory (Onimisi, 2015), that violence was orchestrated by the supporters of General MuhammedBuhari, who was the presidential candidate for Congress for Progressive Change (CPC). Before that violence which swept through Kano, Bauchi, Gombe, Kaduna, and other states, the incumbent governmentwas relentlessly accused of conspiracy to rig the election. The accusation wasaccompanied by blood threats of crisis that the nation will face if the election was rigged (Orji and Ugodi, 2012; Onimisi 2015).

According to Ashindorbe (2018), Violence has become part of Nigeria's political culture that has rendered nearly all elections in Nigeria violent. In his opinion, Alemika (2011) maintains that corruption was the main cause of the 2011 election violence in Nigeria. Explaining further, he argues that the understanding of politics and political office as an investment, and an avenue for acquiring wealth through corruption in a manner, otherwise, not possible through any sort of legitimate vocation and enterprise, made election 'a do or die affair'. As a consequence of this perception and reality, Nigerian politicians turn election campaigning and elections into warfare in which violence and ethnic, religious, and other forms of primordial feelings and prejudices are used (Onimisi 2015). This school of thought was further expanded by Osaghae as he argues thus:

In a civilian dispensation, most businessmen join the party in power to gain access to contracts and other forms of accumulation...all this explains the desperation and opportunism with which political power is sought and use.... This is the major explanation for the warlike approach to elections. (Osaghae, 2015, p. 27).

The self-aggrandization of the dominant class as argued by Ake (1981) creates a situation in which the civic realm constitutes an arena for intergroup struggles for the state's resources. According to this conceptual model, the civic public sphere in which the state belongs is perceived as amoral and a precious booty to be captured and pillaged for the benefit of individuals and groups by any of the contending forces which gain ascendancy at any time (Ashindorbe, 2018). Furthermore, Momoh asserts that:

The State's centrality and primacy as an arena for the primitive accumulation of wealth have resulted in a situation where the stakes during elections are tremendously high which made winning by all means irresistible. As such, physical, structural, and psychological violence are being deployed to 
achieve electoral victories. This is important since 'Primitive Vote Accumulation (PAV)' is intended to serve as the basis for Primitive Power Accumulation (PAP), which in effect serves the Primitive Capital Accumulation (PAC)' (Momoh, 2014, p. 89).

Even with the institutionalization of violence as a strategic means of winning elections, Agbu (2016) and Ashindorbe (2018) argue that, without financial control, election violence may not produce desired outcomes. The assumption of money politics believes that politicians are willing and eager to spray money from the declaration of interest, politics of purchasing nomination, campaigning and organizing thugs, and security agencies that can deliver expected results during an election. Politics has become so lucrative that many can go as far as borrowing, while financier including powerful multi-national institutions often backs them financially as a credible investment. To successfully hit the opponent hard, command fear, or hijack t election materials on the polling day in Nigeria, candidates have to spend a lot of money. To successfully use violence to win an election in a country as hardened as Nigeria, candidates planning such a move will have hire thugs to complement the strength of their support base. He must equip them with sophisticated weapons such as AK47 in other to cause irredeemable anarchy; otherwise, the opponents' support base may repeal and neutralize such planned violence. Finally, from the abundance of literature and as we have highlighted in this paper, the structure of the Nigerian Economy favours unhealthy competition, rivalry, and the patronage of election violence.

\section{Implications for Political Participation}

Studies have shown that electoral violence has numerous consequences, including the disenfranchisement of registered voters, subversion of the majority will, physical assault, and so forth. Violence in elections reproduces the system of authoritarian and undemocratic forces, which undermines confidence in democracy as well as decreases the standard of governance. Even at this, the literature indicates that electoral violence has evenmore devastating consequences for political participation.

Political participation is defined as how individuals or group share their political opinion and contribution towards their governance in terms of engagement, membership to political parties, political ideology, standing for elections, and other civic engagements. All over the world, political participation aims at influencing decision making, acquisition of political powers through elections, and the involvement in how individuals are governed. Political participation represents the single most important aspect of democracy which requires citizens to be fully involved in policy formulation, election procedure, competitive choice, and accountability of their government(Falade, 2014).

Full Political participation of the citizenry is required if democracy is to achieve its fundamental principles of inclusiveness and the government of the popular choice. However, studies have found that electoral violence constitutes a major threat to the political participation of the citizenry. Election violence as we have several defined earlier in this study negates all the democratic norms and remains a threat to the fundamental right to life and property. Election violence is prevalent in Nigeria's version of democracy and has contributed to a lack ofdemocratic consolidation in Nigeria. The impact of election violence on political participation in Nigeria is multi-faced (Sule, and Yahaya, 2019; Egobueze, and Ojirika, 2017).

First, Daxecker (2019) argues that election violence brings about political apathy.Political apathy is a lack of interest in political participation. The show of indifference in political activities includes voter apathy, lack of interest in election processes: campaigning, political events, among others. Political apathy can drastically reduce turn out during elections, thereby, affecting democracy. Lack of political participation can make political office holders unaccountable, corrupt, and dishonest.Election violence also can affect the credibility of the election and legitimacy of the government elected through violence. This scenario is identical to voter apathy, and lack of participation of the citizenry. If an election is won through violence, rigging, and intimidation, the citizenry may lose trust in the system and may decide to abstain from future elections. This scenario can also cause the citizen to hold no obligation to the government. Also, electoral violence can cause a lack of patriotism and disrespect to the law among citizens of a country. The implication of election violence to political participation cannot be overemphasized. But it is pertinent to note that election violence can cause a lot of damages to democratic institutions, political stability, legitimacy of the government, and activism of the citizenry.

\section{Conclusion and Recommendation}

This study usedMarxian theory of the post-colonial state and argues that the structure of the Nigerian political economy is the root cause of electoral violence. This is because the structure is sympathetic to the western neo-colonial capitalist imperialism that encourages the primitive accumulation of wealth. The structure through fiscal federalism created and empowered the dominant class through the overconcentration of financial and administrative powers on the central government. The lack of diverse independent economic enterprises that will drive the economy made the struggle to control the power of the state a lucrative and unrivalled shortcut of amassing wealth. This struggle and selfaggrandizement among the dominant class not only created ethnic sentiment but turn elections in a war where everyone fights dirty for a share of the national cake. The study went further to highlight the implication of election violence on political participation. As such, the study found that election violence tendsto influence political apathy and indifference which can lead to low turnout during elections.

On the strength of our findings, the study made the following recommendations, that:

- There is an urgent need for a constitutional review to reposition the nature and structure of the Nigerian economy to reflect the strength and weakness of each state or region. By this, we mean that each state or region of the country should be given economic autonomy to use what they have or what they can produce and develop 
their area. This will create interdependency among states, where goods and services will be exchanged by barter to complement areas of weakness and export areas of strength

- More functional power should be delegated to the state or region. This should follow-up with a downward review of the enumerations and incentives attached to political offices. By this, we mean that political offices should be made less lucrative.

- Lastly, the study recommends that the government should allow the private sector through anopen and competitive enterprise to drive the economy. By this, we mean that the private sector should be involved more in economic policies and implementation.

\section{References}

i. Adetoye, D. (2016). Nigeria's federalism and state reorganization and restructuring: Attempts at national integration through fragmentation. Journal of Academic Research and Reflection, 4 (2), 309-0405

ii. Adeyeri, 0. (2010). Federalism and the challenges of nation-building in Nigeria.International Journal of Research in Arts and Social Sciences, vol. 2, 23-38

iii. Adibe, R. C., \&Mbaegbu, C. C. (2017). Executive- legislative relations and governance trajectories in Nigeria. South East Political Science Review, I (1), 49-69

iv. Ahmady, Mehrpour, Nikooravesh (2016). 3rd International Conference on New Challenges in Management and Organization: Organization and Leadership. Journal of Social and Behavioral Science

v. Ake, C. (1981). A political economy of Africa. Lagos: Longman.

vi. Alavi, H. (1973). The state in the post-colonial societies: India and Pakistan. London: Longman

vii. Ashindorbe.K (2018) Electoral Violence and the Challenge of Democratic Consolidation in Nigeria.India Quarterly, 74(1) 92-105

viii. Atelhe, A. G. Lawal, A. M, and Terhile, A. (2019). Democracy, Intra-Party Struggle and Good Governance in Nigeria: The People's Democratic Party and all Progressive Congress Experience. European Journal of Scientific Research, Vol. 154 (4), pp. 491 -498

ix. Aver, T. H., Nnorom, K. C., and Targba, A. (2013). Political Violence and its Effects on Social Development in Nigeria. International Journal of Humanities and Social Science, 3(17): 261-266.

x. Beetseh and Akpoo, (2015).The Analysis of the use of Smart Card Reader (SCR) and Credible Elections in Nigeria 2015.International Journal of Political Science and Development, Vol. 3(11), pp. 470-477

xi. Daxecker, U. (2019). Electoral contention and violence (ECAV): A new dataset. Journal of Peace Research, Vol. 56(5) 714-723

xii. Edo and Ikelegbe (2014).The Nigerian Economy Reforms, Emerging Trends and Prospects.International Development and Research Centre, Series No. 8

xiii. Egobueze, A. and Ojirika, C. (2017). Electoral Violence in Nigeria's Fourth Republic: Implications for Political Stability. Journal of Scientific Research \& Reports, volume 13(2): 1-11

xiv. Egobueze, A. and Ojirika, C. (2017). Electoral Violence in Nigeria's Fourth Republic: Implications for Political Stability. Journal of Scientific Research \& Reports, volume 13(2): 1-11

xv. Eme, O.I. and Anyadike, N. (2011). Intra and Inter-Party Crisis in Nigeria's Fourth Republic: Implications for the Sustainability and Consolidation of Democracy in Post Third Term Nigeria. Journal of Social Science and public policy, 3.

xvi. Falade (2014) Political Participation in Nigerian Democracy: A Study of SomeSelected Local Government Areas in On State, Nigeria. Global Journal of HUMAN-SOCIAL SCIENCE: Political Science vol 14(5), pp. 223-256

xvii. Forrest (2014) The political economy of civil rule and the economic crisis in Nigeria (1979-84). Review of African Political Economy

xviii. Human Rights Watch, (2011). Nigeria: Post-Election Violence Killed 800. https://www.hrw.org/news/2011/05/16/nigeria-post-election-violence-killed-800. accessed May 10, 2020

xix. Ibeanu, O. (1998). The Nigerian state and politics of democratization. A paper presented at a conference for book project on comparative democratization in Africa: Nigeria and South Africa, Cape Town, May 31- June 1

$x x$. Kwarkye (2019).Roots of Nigeria's election violence.Institute for Security Studies

xxi. Mbah, P.O. (2014). Political Science Theory and their Application in political science Research in Ikenyibe, O.M. and Mbah, P.O. (2014) (ed) An Anthology of Theories for Social Research. Enugu: University of Nigeria Press Ltd.

xxii. Nnoli, O. (1978). Ethnic Politics in Nigeria. Enugu: Fourth Dimension Publishers.

xxiii. Nwaeze, N.C. (2017). True federalism in a well-structured Nigeria: The panacea to her economic Development challenges. Greener Journal of Economics and Accountancy, 6(2) 026-042

xxiv. Ojukwu, C and Olaifa, T. (2014). Challenges of Internal Democracy in Nigeria's Political Parties: The bane of intra-party conflicts in the People Democratic Party of Nigeria. Global Journal of Human Science, 11(3). Pp.2534

xxv. Ojukwu, U. G, Mbah, C. C. and Maduekwe, V.C (2019). Election and Democratic Consolidation: A Study of the 2019 General Elections in Nigeria. Direct Research Journal of Social Science and Education Studies, vol. 6 (4), pp. 53-64

xxvi. Olakunle O. Bamidele, R. Modupe, K. Oluwaseun, O. Magdalene, A. (2019), Trends In Electoral Violence In Nigeria. Journal of Social Sciences and Public Policy, Volume 11, (1), 223-242 
xxvii. Onah\&Nwali (2018). Monetization of electoral politics and the challenge of political exclusion in Nigeria.Commonwealth \& Comparative Politics

xxviii. Onapajo, H (2014), Violence and Votes in Nigeria: The Dominance of Incumbents in the Use of Violence to Rig Elections. Africa Spectrum, Vol. 49, (2), pp. 27-51

xxix. Onebamhoi, O.N. (2011). Curbing Electoral Violence in Nigeria: The Imperative of Political Education.International Multidisciplinary Journal, Ethiopia Vol. 5 (5), Serial No. 22.Pp 99-110

xxx. Onimisi (2015).The Prognoses of the 2011 Electoral Violence in Nigeria and the Lessons for the Future.Mediterranean Journal of Social Sciences, Vol 6 (1)

xxxi. Onimisi, T, and Tinuola, O. L (2019) Appraisal of the 2019 Post-Electoral Violence in Nigeria Malaysian. Journal of Social Sciences and Humanities, Volume 4, (3) pp. 107 - 113

xxxii. Paul, S. O, Audu, E. \&Kayode, E. (2017). Ethnic agitations and the restructuring question.International Journal of Innovative Social Science and Humanities Research, 5(3), 14-24

xxxiii. Salami (2011). Taxation, Revenue Allocation and Fiscal Federalism in Nigeria: Issues, Challenges and Policy Options. Economic Annals, Volume LVI, No. 189

xxxiv. World Bank Group, 2017 Reports on the Nigerian Economy

xxxv. Yusuf (2019). Electoral Violence in Nigeria: Disentangling the Causes. Research on Humanities and Social Sciences, Vol.9, (10) 